\title{
The role of chemotherapy and latest emerging target therapies in anaplastic thyroid cancer
}

This article was published in the following Dove Press journal:

OncoTargets and Therapy

13 September 2013

Number of times this article has been viewed

\author{
Nerina Denaro ${ }^{1,2}$ \\ Cristiana Lo Nigro ${ }^{3}$ \\ Elvio G Russi ${ }^{4}$ \\ Marco C Merlano' \\ 'Oncology Department, AO S Croce e \\ Carle, ${ }^{2}$ Human Pathology Department, \\ Messina University, ${ }^{3}$ Cancer \\ Genetics and Translational Oncology \\ Department, ${ }^{4}$ Radiation Oncology \\ Department, AO S Croce e Carle, \\ Messina, Italy
}

Correspondence: Nerina Denaro Oncology Department, AO S Croce e Carle, Via Michele Coppino 2I, Cuneo 12100 , Messina, Italy Email nerinadenaro@hotmail.com

\begin{abstract}
Anaplastic thyroid cancer represents 1\%-2\% of thyroid cancers. For its aggressiveness, it is considered a systemic disease at the time of diagnosis. Surgery remains the cornerstone of therapy in resectable tumor. Traditional chemotherapy has little effect on metastatic disease. A multimodality approach, incorporating cytoreductive surgical resection, chemoradiation, either concurrently or sequentially, and new promising target therapies is advisable. Doxorubicin is the most commonly used agent, with a response rate of $22 \%$. Recently, other chemotherapy agents have been used, such as paclitaxel and gemcitabine, with superimposable activity and response rates of $10 \%-20 \%$. However, survival of patients with anaplastic thyroid cancer has changed little in the past 50 years, despite more aggressive systemic and radiotherapies. Several new agents are currently under investigation. Some of them, such as sorafenib, imatinib, and axitinib have been tested in small clinical trials, showing promising disease control rates ranging from $35 \%-75 \%$. Referral of patients for participation in clinical trials is needed.
\end{abstract}

Keywords: thyroid cancer, emerging therapies, anaplastic thyroid carcinoma, chemotherapy, radiotherapy

\section{Introduction}

Anaplastic thyroid cancer (ATC) represents 1\%-2\% of all thyroid tumors and is characterized by aggressive, local invasion and common distant metastases. Histologically, ATC is characterized by elevated mitotic rate and lymphovascular invasion. ${ }^{1}$

All patients with ATC are classified by the American Joint Committee on Cancer as having stage IV disease (IVa, intrathyroidal tumors; IVb, gross extrathyroidal; IVc, distant metastases). It affects prevalently the female sex; the ratio 3:1 is lower than the papillary or follicular histotypes. ${ }^{1}$

The peak incidence occurs during the sixth to seventh decades of life. Anaplastic carcinoma has a poor 5-year survival rate (0-25\%). Based on epidemiological studies derived from the Surveillance, Epidemiology and End Results Database, the incidence of ATC has held steady in the United States during the period between 1973 and $2002 .^{1}$

Clinically, patients refer with growing neck mass, dysphagia, cough, neck pain, and dyspnea. ATC is believed to occur from a terminal dedifferentiation of previously undetected long-standing thyroid carcinoma (eg, papillary, follicular).

ATC has a genetic association with oncogenes $C$-myc, $H$-ras, and Nm23. Mutations in $B R A F, R A S$, catenin (cadherin-associated protein) beta 1, PIK3CA,TP53, AXIN1, PTEN, and $A P C$ genes have been found in ATC, and chromosomal abnormalities are common. ${ }^{2,3}$ Figure 1 summarizes the main route of tumor progression and dedifferentiation. 


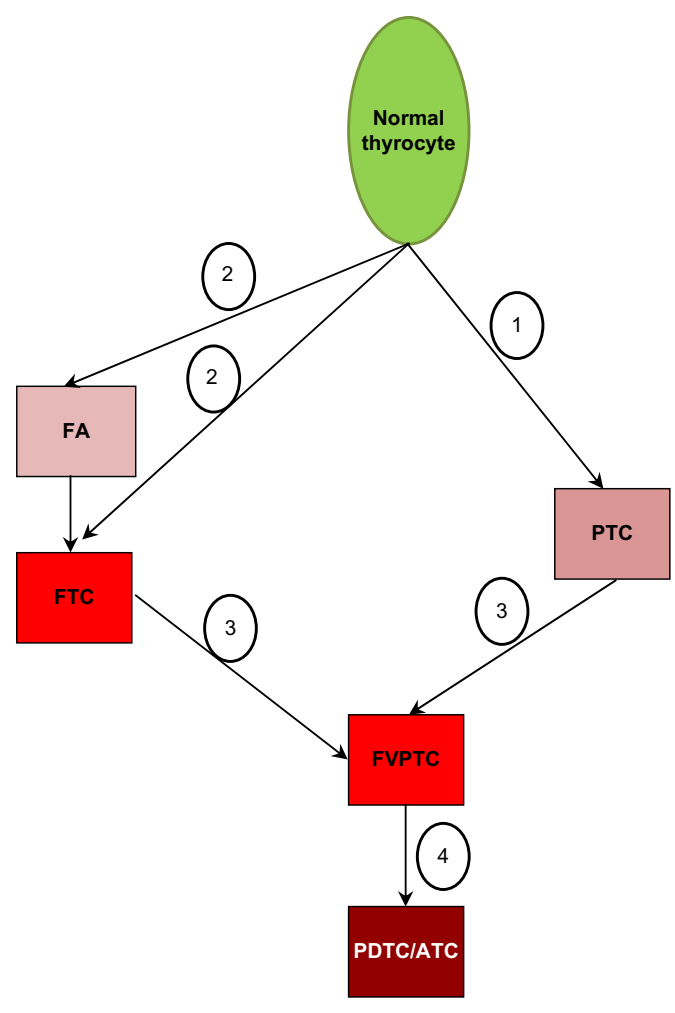

(1) RAS/RAF/MEK, RET/PTC

(2) RAS, PPFP PI3K/AKT aneuploidia

(3) BRAF, PPFP

(4) $\mathrm{p} 53, \mathrm{Rb}, \mathrm{Wnt} / \mathrm{\beta}$-catenin

Figure I The main route of tumor progression and dedifferentiation. Abbreviations: FA, follicular adenoma; FTC, follicular tumor cell; PTC, papillar thyroid carcinoma; FVPTC, follicular variant of papillary thyroid carcinoma; PDTC/ATC, poorly differentiated anaplastic tumor cancer; PPFP, paired box gene 8-peroxisome proliferator activated receptor; PI3K, phosphoinositide 3 kinase; RAS, rat sarcoma; RAF, rapidly accelerated fibrosarcoma; MEK, mitogen activated kinases; RET, rearranged during transfection; AKT, alpha serine/threonine-protein kinase.

Preoperative cervical ultrasonography can detect lymph node metastases. Cervical computed tomography scanning can be used to define the local spread of disease. Detection of distant metastases to the mediastinum, lung, liver, bone, and brain is also possible, via computed tomography scanning or MRI. Bone scanning can be used to determine the presence of bone metastases. Positron emission tomography with ${ }^{18} \mathrm{~F}$-fluorodeoxyglucose can be successfully used in ATC to detect lymph node metastases, lung metastases, and other distant metastases. Fine needle aspiration often yields enough cytological information to allow diagnosis, but sometimes an open surgical biopsy is required. Grossly, ATC is a large, fleshy, off-white tumor. Infiltration of adjacent structures can be observed grossly and microscopically. Histologically, the tumor may contain regions of spontaneous necrosis and hemorrhage. Typically, vascular invasion is detectable. ${ }^{1-73}$

The main histological variants include spindle cell, giant cell (osteoclast-like), squamous, and pauci-cellular. The giant cell subtype typically exhibits local calcification with significant osteoid formation. The pauci-cellular subtype demonstrates rapid growth, intense fibrosis, focal infarction, diffuse calcification, and encroachment of adjacent vascular tissue by atypical spindle cells. ${ }^{4}$

Thyroid lymphoma is the only curable condition that may be confused with ATC. It is fundamental to rule out lymphoma in the presence of a poorly differentiated large cell thyroid tumor. This investigation involves lymphoid tissue markers (eg, cytoplasm immunoglobulin, immunoglobulin receptors, and gene rearrangement studies). When the tumor is surgically resectable, a tracheostomy is often required because of compression of the trachea. Total thyroidectomy is effective in reducing local symptoms produced by the tumor mass. However, surgery alone is not able to control the disease, even in patients with small intrathyroidal masses. ${ }^{1}$

Radiotherapy (RT) is used to improve loco-regional control (LRC), often with chemotherapy (CT). External RT, up to $65 \mathrm{~Gy}$, may slow the progress of the disease but rarely controls it. ATC has a rapid course and early dissemination. ${ }^{20}$ The most common sites of distant spread include, in descending order, the lung, bone, and brain. Metastases, particularly in the lung, are likely to be present at diagnosis more than fifty percent of the time. ${ }^{73}$

CT is often added concurrently with RT but appears to have a limited effect on survival in most studies. ${ }^{10,21,37}$

Some studies report better LRC when RT and CT are administered in a preoperative setting. Whether surgery should be given upfront or after neoadjuvant treatment is an open issue.

However, both the heterogeneity of retrospective series and the absence of randomized trials do not allow recommendation of a standard treatment. Recently, the publication of guidelines by the American Thyroid Association (ATA) ${ }^{74}$ taskforce on ATC offered a significant direction in the management of this disease.

In the last few years, biologically targeted therapies for advanced thyroid carcinomas have been proposed on the basis of the recognition of key oncogenic mutations. New treatments are needed for this highly aggressive malignancy. 
This review will analyze ATC molecular characteristics, preclinical studies results and clinical management, and discuss possible emerging therapies.

\section{Material and methods}

A comprehensive literature review was finalized in February, 2013. Medline ${ }^{\circledR}$ was used for research. Electronic search results were supplemented by hand searching of selected papers, expert consensus meeting notes, and reference lists from selected articles. The literature search was limited to articles in English and humans. The following medical subject heading terms were used in the search: thyroid cancer, emerging therapies, anaplastic thyroid carcinoma, chemotherapy, radiotherapy. We analyzed and discussed the literature, taking into account the previously reported reviews on this matter. In short, we analyzed data from: 29 preclinical studies on genetic ATC alterations and target therapies, 14 clinical reviews, and 38 clinical studies, of these only 17 were prospective studies (see Tables 1 and 2).

\section{Molecular characteristics}

Anaplastic cells do not express thyroid-specific genes; they do not produce thyroglobulin, are unable to transport iodine; and thyrotropin receptors are not found on their plasma membranes.

ATC has a more complex and less distinct gene profile than papillary and follicular cancer, and molecular data suggests it may de-differentiate from well-differentiated thyroid cancer (WDTC). In about one-third of ATC cases, probably those arising from pre-existing papillary differentiated thyroid cancer (PTC), the BRAF(V600E) mutation (2-3) is present. It is also suggested that ATC might develop from RAS-mutated follicular thyroid cancer (FTC), since RAS mutation is also detected in $6 \%-50 \%$ of ATC. ${ }^{2}$ The refractory nature of ATC to therapy may occur, at least in part, due to the presence of cancer stem cells, which have been identified in ATC cell lines. ${ }^{63}$

In ATC, a mutation of PIK3CA gene causing AKT and ERK activation was reported. ${ }^{3,4,68}$ Many of the genetic alterations found in ATC could potentially activate both the MAPK and PI3K/AKT pathways, including RTK gene copy gain, RET/PTC, and RAS mutations. Figure 2 schematizes some of the most important pathways.

The BRAF mutation, which can activate the MAPK pathway, commonly coexisted with genetic alterations that could activate the PI3K/AKT pathway (eg, the PIK3CA copy gain) in ATC. AKT1 was activated in most ATC cases
$(85 \%-93 \%),{ }^{5,6}$ and ERK was activated in $65 \% .{ }^{6}$ Phosphatase and tensin homology encoding chromosome 10 (PTEN) negatively regulates the PI3K pathway, and was mutated in $17 \%$ of 48 cases. $^{7,8}$

Aurora kinases play an important role in cell division, and deregulation may result in aneuploidy. Aurora B is overexpressed in ATC cell lines, ${ }^{9}$ and patient samples had a marked increase when compared with normal thyroid tissue or PTCs. ${ }^{9}$ Like aurora B, aurora A is overexpressed at both the mRNA and protein levels in ATC cell lines, while aurora $\mathrm{C}$ is increased only at the protein level. ${ }^{8}$

Genetic alterations or their combinations that could activate both the MAPK and PI3K/AKT pathways were found in up to $81 \%$ cases of ATC. ${ }^{7}$

PIK3CA/AKT1 mutations and PIK3CA copy gain are frequently identified in ATC, as compared to well differentiated cancer, suggesting that PI3K/mTOR pathway activity is involved in the process of cancer de-differentiation. ${ }^{70}$

Additional mutations frequently observed in ATC involve $\mathrm{p} 53$ and $\beta$-catenin. The tumor-suppressor gene $\mathrm{p} 53$ is fundamental for the progression from indolent to aggressive thyroid cancer. The inactivating p53 mutation, seldom detected in WDTC, is found in about $55 \%$ of PTC and ATC. ${ }^{2}$ Membrane $\beta$-catenin expression is progressively reduced with loss of tumor differentiation, resulting in tumor invasiveness, and increasing metastatic potential. ${ }^{5}$

\section{Treatments}

Treatment of ATC has ranged from surgery, radiotherapy, chemotherapy, or a combination of these regimens. Any modality used alone usually fails to control local disease, which is often the cause of death. Complete resection of ATC in the neck usually is not possible, but surgery can be an effective palliative modality. Extensive radical neck operations with en bloc adjacent organ resection are associated with high morbidity and are probably not warranted for this disease.$^{61}$ Postoperative RT, as well as palliative RT is widely used.

Agents used for chemotherapy usually include doxorubicin and analogs, but paclitaxel, cisplatin, carboplatinum, VP-16, cyclophosphamide, melphalan, and bleomycin are also used.

However, no standards of care for ATC are approved.

This depends on the lack of few statistically significant data in this population. Additionally, due to the rarity of the disease, few patients are enrolled in clinical trials. ATA recommends a comprehensive multimodality plan to establish treatment strategy. 
Table I Treatment of anaplastic thyroid cancer

\begin{tabular}{|c|c|c|c|c|c|}
\hline Series & Year & No & Therapies & Outcomes & Notes \\
\hline $\begin{array}{l}\text { Voutilainen } \\
\text { et } \mathrm{al}^{23}\end{array}$ & 1999 & 33 & $\mathrm{~S} \rightarrow \mathrm{CRT}$ & I-y DSS $=9.7 \%(C l: 2.0-25.9)$ & $\begin{array}{l}\text { Resectability }(P=0.0002), \text { metastases } \\
(P=0.00 \text { I } 4), \mathrm{RT}(P=0.014) \text {, and radioiodine } \\
\text { ablation }(P=0.039)=\operatorname{PrF}\end{array}$ \\
\hline Tan et $\mathrm{al}^{24}$ & 1995 & 21 & $\mathrm{~S} \rightarrow \mathrm{RT} \pm \mathrm{CT}$ & $\begin{array}{l}\mathrm{mOS}=4.5 \mathrm{~m} \\
\text { After radical } \mathrm{S} \\
\mathrm{mOS}=131 \mathrm{~m}\end{array}$ & $\begin{array}{l}T>6.0 \mathrm{~cm}(P=0.004) \text { and female }(P=0.02) \\
=\operatorname{PrF}\end{array}$ \\
\hline Pierie et $\mathrm{a}^{84}$ & 2002 & 67 & $\mathrm{~S} \rightarrow \mathrm{RT} \pm \mathrm{CT}$ & $\begin{array}{l}\text { I-y OS }=92 \% \mathrm{a} \\
3 \text {-y OS }=83 \% \mathrm{a} \\
\text { After debulking: } \\
\text { I-y OS }=35 \% \\
3 \text {-y OS }=0 \% \\
\text { After no resection: } \\
\text { I-y OS }=4 \% \\
3 \text {-y OS }=0 \%(P<0.000 \mathrm{I})\end{array}$ & $\begin{array}{l}\text { Better OS for RT }>45 \text { Gy } \\
\text { than }<45 \text { Gy }(P=0.02) \\
\text { - Age } \leq 70 \text { y } \\
\text { - Absence of dyspnea or dysphagia } \\
\text { at presentation, } T \leq 5 \mathrm{~cm} \text {, and surgery } \\
(P<0.05)\end{array}$ \\
\hline $\begin{array}{l}\text { Schlumberger } \\
\text { et } \mathrm{al}^{26}\end{array}$ & $199 \mid$ & 20 & $\begin{array}{l}<65 \mathrm{y} \rightarrow \text { doxorubicin }\left(60 \mathrm{mg} / \mathrm{m}^{2}\right)+ \\
\text { cisplatin }\left(90 \mathrm{mg} / \mathrm{m}^{2}\right)+\mathrm{RT} \\
>65 \mathrm{y} \rightarrow \text { mitoxantrone } \\
\left(14 \mathrm{mg} / \mathrm{m}^{2}\right)+\mathrm{RT}\end{array}$ & OS $>20 \mathrm{~m}$ in $3 / 20$ patients & $\begin{array}{l}\text { Multimodal treatment improves OS and LRC. } \\
\text { Gross tumor resection should be performed } \\
\text { whenever possible }\end{array}$ \\
\hline Mitchell et a ${ }^{27}$ & 1999 & 17 & RT twice daily, DT $60.8 \mathrm{~Gy}$ & 5/I7 CR, 7/I7 PR, 5/I7 SD & $\begin{array}{l}\text { High toxicity from esophagitis and dysphagia } \\
\text { RR to RT but toxicity was unacceptable }\end{array}$ \\
\hline Besic et a ${ }^{28}$ & 2005 & 188 & $\mathrm{~S} \rightarrow \mathrm{CT} \pm \mathrm{RT}$ & $\begin{array}{l}\mathrm{mOS}=3 \mathrm{~m} \\
1-\mathrm{y} O S=13 \% \\
2-y \mathrm{OS}=6 \%\end{array}$ & $\begin{array}{l}\text { Age, PS, tumor growth, tumor extension, and } \\
\text { distant metastases = independent } \operatorname{PrF}\end{array}$ \\
\hline $\begin{array}{l}\text { De Crevoisier } \\
\text { et } \mathrm{al}^{29}\end{array}$ & 2004 & 30 & $\begin{array}{l}\mathrm{S} \rightarrow 2 \times \mathrm{CT} \rightarrow \mathrm{RT} \rightarrow 4 \times \mathrm{CT} \\
\mathrm{CT}=\text { doxorubicin }\left(60 \mathrm{mg} / \mathrm{m}^{2}\right) \\
\text { and cisplatin }\left(120 \mathrm{mg} / \mathrm{m}^{2}\right)\end{array}$ & $\begin{array}{l}3-y \text { OS }=7 \%(95 \% \mathrm{Cl}: 10 \%-44 \%) \\
\text { mOS }=10 \mathrm{~m} \\
\text { Death due to local PD in } 5 \% \\
\text { and distant PD in } 68 \% \\
\text { and to both in } 27 \%\end{array}$ & $\begin{array}{l}\text { Main toxicity was hematologic. High long- } \\
\text { term OS with postop CRT }\end{array}$ \\
\hline $\begin{array}{l}\text { Brignardello } \\
\text { et } \mathrm{al}^{22}\end{array}$ & 2007 & 47 & $\begin{array}{l}\mathrm{CRT} \rightarrow \mathrm{S} \rightarrow \mathrm{CT} \text { or } \\
\mathrm{S} \rightarrow \mathrm{CRT} \text { or } \\
\mathrm{CT}\end{array}$ & & $\begin{array}{l}\text { Maximal debulking followed by adjuvant CRT } \\
\text { was the only treatment that modified OS } \\
\text { (hazard ratio }=0.23,95 \% \mathrm{Cl}: 0.07-0.79 \text { ) }\end{array}$ \\
\hline Haigh et $\mathrm{al}^{21}$ & 2000 & 33 & $\mathrm{CRT}^{*} / \mathrm{CRT}^{*} \rightarrow \mathrm{S}$ & $\mathrm{OS}=3.8 \mathrm{~m}$ & Surgery improved outcome \\
\hline $\begin{array}{l}\text { Kobayashi } \\
\text { et al }{ }^{30}\end{array}$ & 1996 & 37 & CRT* exclusively & NR & $\begin{array}{l}\text { Main toxicity was hematologic. Some long- } \\
\text { term OS with postop CRT }\end{array}$ \\
\hline $\begin{array}{l}\text { Swaak-Kragten } \\
\text { et al }{ }^{31}\end{array}$ & 2009 & 75 & $\mathrm{CRT}^{*}$ & $\mathrm{I}-\mathrm{y} O S=9 \%$ & $\begin{array}{l}\text { LRC higher in R0/RI resection or CRT, } \\
\text { with best results with } \mathrm{S}+\mathrm{CRT} \text { (CR in } 89 \% \text { ) }\end{array}$ \\
\hline Vrbic et $\mathrm{al}^{32}$ & 2009 & 16 & $\mathrm{CRT}^{* * *}$ & $\begin{array}{l}\text { ORR }=25 \%(95 \% \mathrm{Cl}: 7-55) \\
\text { OS }=11.0 \mathrm{~m}(95 \% \mathrm{Cl}: 8.56-13.44)\end{array}$ & Long OS with Doxo + cisplatin \\
\hline Yau et $\mathrm{al}^{33}$ & 2008 & 50 & $\begin{array}{l}S \\
S+T \\
S+C R T\end{array}$ & $O S=97 \mathrm{~d}$ & $\begin{array}{l}\text { Age } \leq 65(P \leq 0.0 \mathrm{I}) \text {, no metastatic disease } \\
\text { at presentation }(P<0.0 \mathrm{I}) \text {, surgery } \\
(P<0.0 \mathrm{I}) \text {, and postop RT }=\text { prF } \\
\text { CT was not associated with longer OS }\end{array}$ \\
\hline Lim et $\mathrm{al}^{34}$ & 2007 & 37 & aRT & $\begin{array}{l}2-y \text { LRC }=25 \% \\
P F S=8 \% \\
O S=18 \%\end{array}$ & Better RR and LRC \\
\hline Yau et $\mathrm{al}^{33}$ & 2006 & 15 & $\mathrm{~S} \rightarrow \mathrm{RT}$ & $O S=237 d$ & $\begin{array}{l}6,12,18 \text {, and } 24-\mathrm{m} \text { OS }=33 \%, 26 \% \text {, } \\
13 \% \text {, and } 0 \% \text {, respectively }\end{array}$ \\
\hline Wang et $\mathrm{al}^{20}$ & 2006 & 47 & SRT vs HRT & $O S=11 \mathrm{~m}$ & $\begin{array}{l}\text { 6-m } L R C=95 \%(P=0.000 \mathrm{I}) \text { with } \mathrm{RT} \text { at } \\
40 \mathrm{~Gy} \text { vs } 64 \% \mathrm{RT} \text { at }<40 \mathrm{~Gy} \text {. } \\
\text { mOS with HRT: I } 3 \mathrm{~m} \text { vs } 10 \mathrm{~m} \mathrm{SRT}(P=0.3)\end{array}$ \\
\hline Veness et $\mathrm{al}^{25}$ & 2004 & 18 & $\mathrm{~S}+\mathrm{RT}$ & $\mathrm{OS}=6.2 \mathrm{~m}$ & Single modality correlates with worst prognosis \\
\hline Haigh et $\mathrm{al}^{21}$ & 2001 & 33 & $\mathrm{~S}+\mathrm{RT}$ & $\mathrm{OS}=43 \mathrm{~m}(\mathrm{R} 0)$ & $\begin{array}{l}\mathrm{mOS}=3.3 \mathrm{~m} \text { with only } \mathrm{CT} \text { and } \mathrm{RT} \\
\text { and palliative resection }(P=0.63)\end{array}$ \\
\hline Mclver et $\mathrm{al}^{36}$ & 2001 & 134 & $S \rightarrow R T$ vs $S$ & $\mathrm{mOS}=3-5 \mathrm{~m}$ & $\begin{array}{l}\text { Extent of resection did not affect survival } \\
(P>0.4)\end{array}$ \\
\hline
\end{tabular}


Table I (Continued)

\begin{tabular}{|c|c|c|c|c|c|}
\hline Series & Year & No & Therapies & Outcomes & Notes \\
\hline \multirow[t]{2}{*}{ Besic et $\mathrm{al}^{28}$} & 2001 & 162 & $\mathrm{~S} \rightarrow \mathrm{CRT}$ & & I-y OS preop versus postop CRT $(P=0.17)$ \\
\hline & & & $\mathrm{CRT} \rightarrow \mathrm{S}$ & & \\
\hline \multirow[t]{4}{*}{ Heron et $\mathrm{al}^{38}$} & 2002 & 32 & SRT & $2-y$ OS $=44 \%$ & $\mathrm{HRT}+\mathrm{CT}$ is associated with better OS but \\
\hline & & & $\mathrm{aRT}+\mathrm{CT} * * *$ & $\mathrm{PFS}=53 \%$ & not PFS \\
\hline & & & & $2-y$ OS $=52 \%$ & \\
\hline & & & & $\mathrm{PFS}=38 \%$ & \\
\hline \multirow[t]{2}{*}{ Nilsson et a $\mathbf{l}^{39}$} & 1998 & 81 & $\mathrm{CRT}^{*} / \mathrm{CRT}^{*} \rightarrow \mathrm{S}$ & $2-y$ OS $=90 \%$ & OS $>2 y$ in $10 \%$ pts treated with \\
\hline & & & & $\mathrm{OS}=4.3 \mathrm{~m}$ & $\mathrm{CT}+\mathrm{RT}+\mathrm{S}$ \\
\hline \multirow{3}{*}{$\begin{array}{l}\text { Tennvall } \\
\text { et a }\left.\right|^{40}\end{array}$} & 1994 & 33 & $\mathrm{aRT}+$ doxorubicin $+\mathrm{S}$ & $L F=24 \%$ & Preop RT 30 Gy and postop RT 46 Gy + \\
\hline & & & & & $20 \mathrm{mg}$ doxo-weekly \\
\hline & & & & & $\mathrm{aRT}>\mathrm{LRC}$ \\
\hline Junor et $\mathrm{a}^{41}$ & 1992 & 91 & $S+R T$ & & Postop RT improve outcomes \\
\hline Levendag & 1993 & 51 & $S+R T$ & OS $=7.5 \mathrm{~m}$ & Achievement of $C R$ is an important goal \\
\hline et $\mathrm{al}^{42}$ & 2011 & 44 & & $m Q 5$ f responders - $284 \mathrm{~m}$. & $\begin{array}{l}\text { of therapy } \\
\text { s sionificantly lower in }\end{array}$ \\
\hline \multirow{3}{*}{ Derbel et $\mathrm{al}^{43}$} & 2011 & 44 & $\begin{array}{l}S \\
S+R T\end{array}$ & $\begin{array}{l}\mathrm{mOS} \text { of responders }=28.4 \mathrm{~m} \\
\mathrm{mOS} \text { of progressive }=5.1 \mathrm{~m}\end{array}$ & $\begin{array}{l}\text { mUS significantly lower in pts undergoing } \\
\text { palliative surgery }\end{array}$ \\
\hline & & & $S+C R T$ & & \\
\hline & & & RT & & \\
\hline Kim and & 1987 & 41 & $\mathrm{aRT}+\mathrm{CT}$ & $C R=84 \%$ & aRT $+C T$ is feasible and achieves good \\
\hline \multirow[t]{2}{*}{ Leeper ${ }^{10}$} & & & & $\mathrm{LRC}=68 \%$ & response \\
\hline & & & & $O S=I y$ & \\
\hline
\end{tabular}

Notes: after complete resection; *doxorubicin; **doxorubicin $60 \mathrm{mg} / \mathrm{m}^{2}$ and cisplatin $40 \mathrm{mg} / \mathrm{m}^{2}$ every 3 weeks; ***doxorubicin, paclitaxel, vincristine, or cisplatin. Abbreviations: T, tumor; PrF, prognostic factors (for OS); y, years; m, months; D, days; OS, overall survival; ORR, overall response rate; Cl, confidence interval; LRC, locoregional control; CRT, chemoradiation; CR, complete remission; aRT, altered fractionated RT; SRT, standard RT; HRT, hyperfractionated RT; R0, radically resected; Doxo, doxorubicin; DSS, disease specific survival; RR, response rate; CR, complete response; PR, partial response; SD, standard response; PS, performance status; PD, progressive disease; Preop, preoperative; Postop, postoperative; mOS, median overall survival; S, surgery; CT, chemotherapy; pts, patients; RT, radiotherapy; vs, versus; RI, resection indicated that the margins of the resected parts show tumor cells when viewed microscopically; CDDP, cisplatin.

Table 2 Most significant trials on molecular target therapies used in anaplastic thyroid cancer treatment

\begin{tabular}{|c|c|c|c|c|}
\hline Study & Drug & Target & Phase & Outcome \\
\hline Kim et $\mathrm{al}^{44}$ & AEE788 & EGFR VEGFR & $\mathrm{P} * *$ & Increase apoptosis, inhibit cell proliferation \\
\hline Fury et $\mathrm{al}^{51}$ & Gefitinib & Multikinase & Phase I & Growth inhibition \\
\hline Gupta-Ambramson et $\mathrm{al}^{53}$ & Sorafenib & Multikinase & Phase II-III & Growth inhibition \\
\hline Jin et $\mathrm{al}^{177}$ & $\begin{array}{l}\text { AZD6244 + } \\
\text { everolimus }\end{array}$ & $\begin{array}{l}\text { MEK inhibitors + } \\
\text { mTOR inhibitor }\end{array}$ & $\mathrm{P} * *$ & $\begin{array}{l}60 \% \text { growth inhibition with combined MEK } \\
\text { and mTOR inhibition }\end{array}$ \\
\hline Rosove et $\mathrm{al}^{59}$ & PLX4720 & BRAF inhibitors & $\begin{array}{l}\text { Case } \\
\text { report }\end{array}$ & $\begin{array}{l}{ }^{18} \mathrm{~F}-\mathrm{FDG}-\mathrm{PET} \text { and computed tomography of the } \\
\text { chest on day } 38 \text { showed nearly complete clearing } \\
\text { of metastatic disease }\end{array}$ \\
\hline Catalano et al ${ }^{16}$ & VPA & Deacetylase inhibitors & Phase II & Enhance chemo-sensitivity and radio-sensitivity \\
\hline Gule et $\mathrm{a}^{56}$ & Vandetanib & Cellular matrix & $\mathrm{P} * *$ & $66 \%-69 \%$ growth inhibition \\
\hline Cohen et $\mathrm{al}^{52}$ & Axitinib & Multikinase & Phase II & $\begin{array}{l}\text { Median PFS = } 18.1 \mathrm{~m} . \text { Decreased sVEGFR-2 } \\
\text { and sVEGFR-3 plasma concentrations versus sKIT }\end{array}$ \\
\hline Liu and Xing ${ }^{8}$ & MK2206 & PI3K inhibitors & $\mathrm{P} * *$ & Growth inhibition \\
\hline Catalano et $\mathrm{al}^{78}$ & Panobinostat & Deacetylase inhibitor & $\mathrm{P} *$ and $\mathrm{P} * *$ & $\begin{array}{l}\text { Significant reduction of } \mathrm{Ki} 67 \text { reduce tumor } \\
\text { volume and growth }\end{array}$ \\
\hline Papewalis et a $7^{79}$ & Everolimus & mTOR inhibitor & $\mathrm{P} * *$ & Growth inhibition \\
\hline Nehs et al $7^{70}$ & PLX4720 & BRAF inhibitors & $\mathrm{P}^{*}$ & $\begin{array}{l}\text { Neoadjuvant PLX } 4720 \text { could be an effective } \\
\text { therapeutic strategy for early anaplastic thyroid } \\
\text { cancers that harbor the BRAF(V600E) }\end{array}$ \\
\hline Savvides et $\mathrm{a}^{71}$ & Sorafenib & Multikinase & Phase II & $\begin{array}{l}10 \% \text { PR } \\
25 \% \text { stable disease: } P F S=1.9 \mathrm{~m}, \mathrm{mOS}=3.9 \mathrm{~m}, \\
\mathrm{I}-\mathrm{y} \text { survival OS }=20 \%\end{array}$ \\
\hline Cooney et $\mathrm{a}^{75}$ & Combretastatin & $\begin{array}{l}\text { Tubulin binding vascular } \\
\text { disrupting agent }\end{array}$ & Phase II & $\begin{array}{l}33 \% \text { DCR } \\
\text { I patient had } 30 \mathrm{~m} \text { PFS }\end{array}$ \\
\hline Ha et $\mathrm{al}^{76}$ & Imatinib & Multikinase & Phase II & DCR $75 \%$ \\
\hline Sosa et $a^{83}$ & Combretastatin & Multikinase & Phase III & $\mathrm{mOS}=5 \mathrm{~m}$ \\
\hline
\end{tabular}

Notes: *Orthotopic mouse model; **ATC cell lines.

Abbreviations: P, preclinical; mTOR, mammalian target of rapamycin; PR, partial response; SD, stable disease; m, months; OS, overall survival; DCR, disease control rate; PFS, progression free survival; EGFR, epidermal growth factor receptor; VEGFR, vascular endothelial growth factor receptor; MEK, mitogen activated kinases; PI3K, phosphoinositide 3 kinases; mOS, median overall survival; ${ }^{18} \mathrm{~F}-\mathrm{FDG}-\mathrm{PET}$; ${ }^{18} \mathrm{~F}$-fluorodeoxyglucose positron emission tomography; VPA, valproic acid; s, serum. 


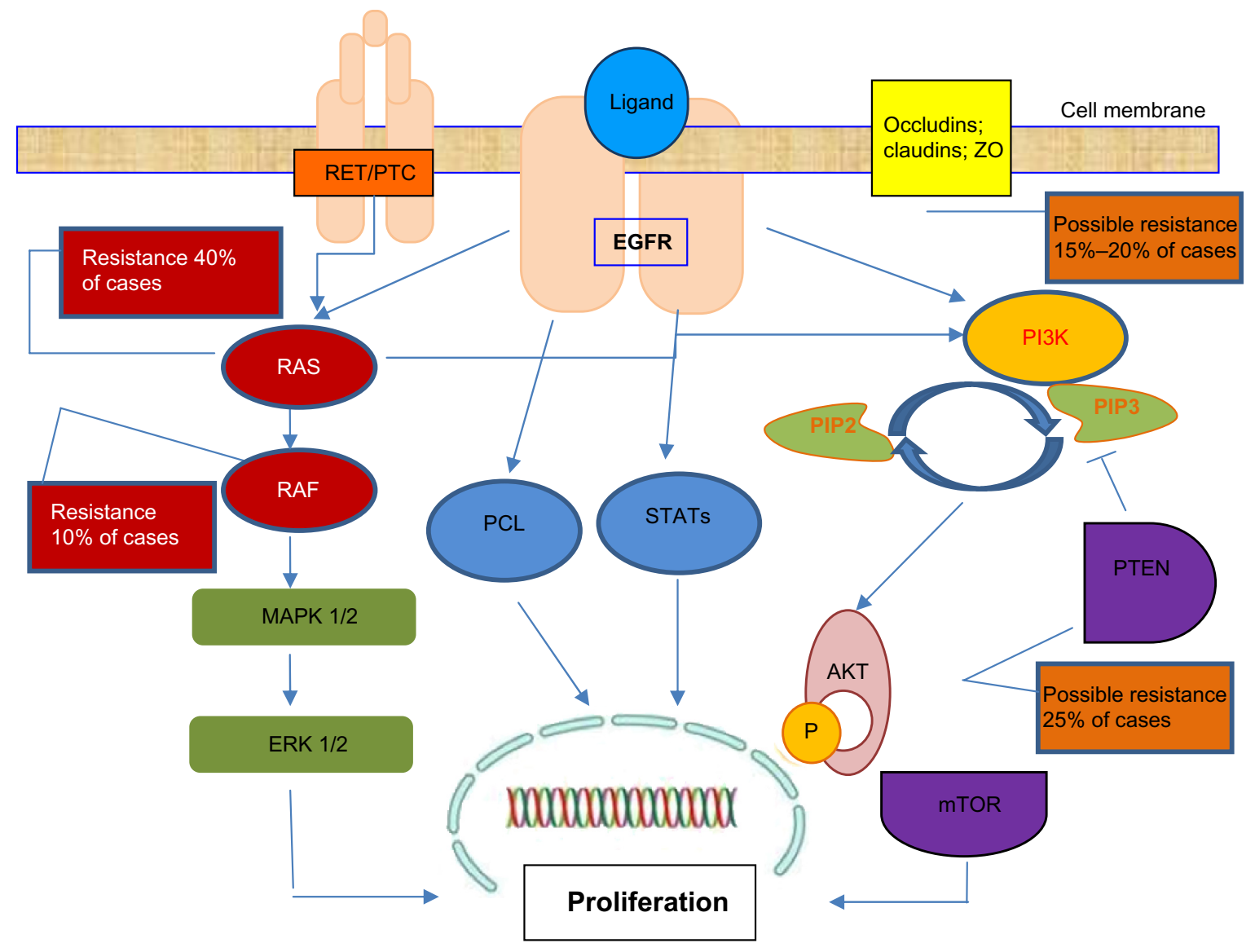

Figure 2 Anaplastic thyroid cancer growth pathways.

Note: The MAPK/ERK/PTEN pathway is a chain of proteins that communicates a proliferation signal from a receptor on the surface of the cell to the DNA in the nucleus of the cell.

Abbreviations: MAP, Mitogen-activated protein; ZO, zonula occludens; MAPK, MAP kinase; mTOR, mammalian target of rapamycin; ERK, extracellular signal-regulated kinase; PI3K, phosphoinositide 3 kinase; RET, rearranged during transfection; EGFR, epidermal growth factor receptor; RAS, rat sarcoma; RAF, rapidly accelerated fibrosarcoma; PIP, phosphatidylinositol phosphate; PTC, papillary thyroid cancer; AKT, alpha serine/threonine-protein kinase; PTEN, phosphatase and tensin homolog; P, phosphate; PCL, phospholipase C.

\section{Radiotherapy}

Radiotherapy for ATC has changed from palliative low dose of standard RT to altered fractionation RT (hyper fractionation) and higher dose ( $>40 \mathrm{~Gy})$. Since ATC is a rapidly dividing tumor, hyperfractionated RT or the combination of CRT minimizes tumor cell repopulation. External beam RT to the neck or mediastinum was administered to total doses ranging from $45-75 \mathrm{~Gy} .{ }^{1}$

Wang et al (2006) demonstrate the importance of a radical dose of radiotherapy: ie, patients with good performance status and no distant metastases who received radical radiotherapy ( $>40 \mathrm{~Gy}$ ) versus [vs] those with poor performance status or distant metastases, had a median survival of 11.1 and 3.2 months, respectively. ${ }^{20}$

High dose accelerated RT improves the response rate to RT but toxicity is hardly manageable. Hyperfractionated RT seems to be more effective for local control than conventional treatment. ${ }^{27}$
Several authors have assessed the efficacy and feasibility of postoperative radiotherapy. Higher locoregional control is associated with accelerated RT and free surgical margins. ${ }^{40}$

\section{Chemotherapy and chemoradiotherapy}

Doxorubicin was considered the most effective drug for ATC until a few years ago. In a randomized study of ECOG, the combination of cisplatin and doxorubicin was shown to be more effective than doxorubicin alone, with higher complete RR.

Combination chemotherapy with bleomycin, doxorubicin, and cisplatin resulted in a response rate of $40 \%$ in advanced thyroid cancer, producing considerable palliative effects. It is noteworthy that best responses to this regimen were observed often in patients with ATC. ${ }^{11}$ Several other reports confirmed that a combination $\mathrm{CT}$ versus doxorubicin alone is more effective (RR 5\% vs $18 \%$ ). ${ }^{17}$ 
Preclinical studies showed that paclitaxel inhibited growth in multiple ATC cell lines, ${ }^{13}$ causing cell cycle arrest, apoptosis, and phosphorylation of multiple signaling kinases (JNK, ERK, AKT1). ${ }^{12}$ Based on preclinical data, an open-label Phase II clinical trial of paclitaxel as a 96-hour infusion was conducted, achieving a favorable outcome: overall response rate $(\mathrm{ORR})=53 \%$, disease progression $(\mathrm{DP})=42 \%$, stable disease $(\mathrm{SD})=5 \%$, partial regression $(\mathrm{PR})=47 \%$, or complete regression $(C R)=5 \%$; overall survival $(O S)=6 \mathrm{~m}$, median survival $(\mathrm{mOS})=7$ and 32 weeks in responders and non-responders respectively. ${ }^{14}$

Long-term survivors were also reported among patients with stage $\mathrm{IVb}$ and IVc disease using weekly paclitaxel administration as induction $\mathrm{CT},{ }^{15}$ while no significant $\mathrm{OS}$ difference was assessed among stage IVc patients. ${ }^{13}$

The paclitaxel effects on apoptosis and tubulin acetylation are both enhanced by the histone deacetylase inhibitor, valproic acid. ${ }^{16}$

Inhibition of cell cycle progression is an important strategy for reducing tumor growth: in ATC cell lines, gemcitabine, a nucleoside analog, induces G1/S arrest. The cytotoxic effect is additive if followed by cisplatin. Of interest, these drugs produce an antagonistic response when given in reverse order, as cisplatin inhibits gemcitabine incorporation into DNA. ${ }^{12}$

Chemotherapy improved the effect of RT in locoregional and distant control. Weekly administration of low-dose doxorubicin concurrently with RT showed an acceptable toxicity and may be a therapeutic option for patients with ATC (2-y LRC: 68\%; mOS: 1 y). ${ }^{10}$

Haigh et $\mathrm{al}^{21}$ reported the results of resected patients treated with CRT; with 8/26 patients being long survivors after postoperative CRT. In patients treated with potentially curative resection, median survival was 43 months compared with 3 months with palliative resection $(P<0.002){ }^{21}$

No association was found between survival and age, prior goiter, prior thyroid carcinoma, adjacent differentiated carcinoma, or tumor size.

Table 1 reports some of the most impressive studies using RT and CT therapies in ATC.

In Turin, Italy, 27 patients were treated in a 5-year period. ${ }^{22}$ Surgery was performed initially (maximum debulking in 11 and palliative in 6). Chemotherapy (doxorubicin + cisplatin) was given during and after radiation. The approach in five patients was neoadjuvant CRT followed when possible by surgery, while five others had paclitaxel therapy alone. As in other series, surgical resection was the major contributor to patient responses. While median survival was only 3.9 months, those with maximal debulking had a 6-month survival of 58\%; those with palliative or no surgery, only $10 \% .^{22}$

Akaishi et al reported a retrospective series of 100 patients with ATC, treated between 1993 and 2009. Patients received surgery followed by RT with or without CT. Nineteen of the 100 patients survived for more than 1 year, and most of these underwent a complete resection, as opposed to debulking, followed by adjuvant radiotherapy with or without chemotherapy. However, the overall survival at 2 years remains dismal $(12.3 \%) .{ }^{37}$

\section{Emerging therapies}

There is a growing interest in target therapies and preclinical findings, in order to improve the dismal results obtained with conventional chemotherapy and chemoradiation in ATC.

Much has been learned about the genes, RNAs, and proteins deregulated. A lot of new drugs have been investigated but only few were demonstrated to be effective in both preclinical and clinical investigations. ${ }^{79-82}$

\section{EGFR inhibitors}

The frequent presence of endothelial growth factor receptor (EGFR) in ATC tumors and pleiotropy of its effects makes it an attractive target for drug development. Gefitinib, a tyrosine kinase inhibitor, slows down cell growth, although high doses are necessary in ATC cells. Early stage clinical trials have been performed in combination with docetaxel but results are dismal. ${ }^{45,46}$

The monoclonal antibody cetuximab should induce apoptosis but evidence for this is conflicting. ${ }^{46,47}$ In preclinical trials, Kim et $\mathrm{al}^{85}$ observed that combination therapy with cetuximab/irinotecan inhibits the growth and progression of orthotopic ATC in nude mice.

An interesting dual inhibitor of EGFR and vascular EGFR (VEGFR), AEE788, was shown in ATC cells to increase apoptosis and inhibit both cell proliferation and the phosphorylation of multiple proteins. ${ }^{44,47}$ Kim et al (2005) showed that dual inhibition in combination with paclitaxel, is effective. ${ }^{44}$

\section{Multikinase inhibitors, mTOR inhibitors, MEK inhibitors, and other emerging therapies}

Imatinib, another tyrosine kinase inhibitor with multiple targets, (eg, BCR-ABL1; c-KIT; PDGFR) has variable activity in ATC cell lines. ${ }^{44-46}$ However, imatinib does not achieve its effects at clinically achievable concentrations, although a recent clinical trial in 11 patients achieved a disease control rate in 6, with 6-month PFS $=27 \%$ and 6-month OS $=46 \% .{ }^{75}$ 
Other agents that have shown cytostatic effects in preclinical settings are in the clinical phase of investigation, such as plitidepsin, TP53-expressing adenovirus, mammalian target of rapamycin (mTOR) inhibitors and thiazolidinediones (TZDs), MEK inhibitors (AZD6244), tubulin-binding agents, and combretastatin A. ${ }^{48-50}$

Combretastatin A (CA4P) achieved satisfactory results in Phase II-III studies; ${ }^{76}$ in the Phase III trial, its combination with carboplatin and paclitaxel showed a $35 \%$ reduction in the risk of death $(1-\mathrm{y}$ OS $=27 \%$ vs $9 \%$ with $\mathrm{CT}+\mathrm{CA} 4 \mathrm{P}$ vs CT respectively; $P=0.065){ }^{83}$

Unsatisfactory results were obtained with axitinib and pazopanib monotherapy, even if an association of pazopanib and paclitaxel appears promising. ${ }^{52,53}$ Nevertheless, most of these trials with targeted agents were based on limited numbers of patients; therefore, all interesting results should be confirmed.

However, at the 2012 Italian Oncology Meeting, Spallanzani et al presented experience from Modena University Hospital with TKIs: 9 patients treated with sunitinib ( 7 patients) and sorafenib ( 2 patients) confirmed the efficacy and safety profile of TKIs in ATC. ${ }^{58}$

A Phase II study of sorafenib in ATC patients ${ }^{71}$ and an international multicenter Phase III trial of sorafenib versus placebo in patients with iodine-refractory thyroid cancer (NCT00984282) ${ }^{72}$ are ongoing.

Given the genomic instability of ATC, effective therapies may benefit from comprehensive microarray analysis or genome-wide screening to develop an individualized therapeutic regimen that maximally inhibits major pathways at multiple genetic and epigenetic levels. In addition, to more fully characterize the complex molecular profile, subsequent rapid in vitro screening assays of combinations of targeted therapies may further optimize a patient's treatment plan. Finally, refinement may derive from evolving drug delivery systems such as nanoparticles. ${ }^{63,64}$

Recently valproic acid (VPA) was investigated in preclinical studies and showed highly efficacy in suppressing the growth of poorly differentiated thyroid cancer cell lines, inducing apoptosis and cell cycle. Its activity is limited in VPA monotherapy but it may be added to CT, as it enhances the cytotoxicity of doxorubicin and increases radiosensitivity. ${ }^{16-44}$

Panobinostat (LBH589) is a hydroxamic acid with potent inhibitory activity at low nanomolar concentrations against all classes of histone deacetylases (pan-deacetylases inhibitor). ${ }^{55-80}$

In vitro treatment with LBH589 resulted in impairment of cell viability, inhibition of colony formation, cell cycle arrest, and apoptosis induction. Recently, it has been reported that two histone deacetylase inhibitors, trichostatin A and vorinostat, induced miR-129-5p overexpression, histone acetylation, and cell death in papillary and anaplastic cancer cell lines, and in primary cultures of papillary thyroid cancer.

Disruption of the E-cadherin/catenin complex contributes to tumor metastasis, and decreased expression of E-cadherin is observed in advanced stage, poorly differentiated carcinomas, and is associated with the transformation of differentiated carcinomas. Loss of E-cadherin is associated with the transformation in ATC. ${ }^{69}$

Wunderlich et $a 1^{57}$ reported that vandetanib inhibited tumor growth of the ATC cell lines in vivo (Hth83 and $8505 \mathrm{C}$ by $69.3 \%[P<0.001]$ and $66.6 \%[P<0.05]$, respectively), when compared to control. The authors concluded that the tremendous in vivo anti-tumor activity of vandetanib against ATC makes it an attractive candidate for further preclinical as well as clinical development for the treatment of this particularly virulent cancer, which remains effectively untreatable..$^{57}$

Inhibition of the proteasome pathway with bortezomib is also a strategy to evaluate in in-vivo experiments, as it showed proapoptotic activity on ATC. ${ }^{58}$

Aurora kinases inhibitors (MLN8054) had proapoptotic and antiproliferative effects in ATC cells. The antitumoral activity is increased with the association of bortezomib. ${ }^{83}$

Another critical serine-threonine protein kinase involved in the MAPK pathway that has been targeted to block its constitutive kinase activation is BRAF. ${ }^{66,67}$

BRAF mutation (V600E) is reported in 24\% of papillary-derived ATC. Preclinical and clinical studies investigating combination therapy with agents such as selective (PLX4032) and potent (BAY 73-4506 and ARQ 736) small-molecule BRAF inhibitors, and MAP/ERK kinase inhibitors (AZD6244) hold great promise in the treatment of BRAF(V600E) ATC. ${ }^{65,66,68}$

In a mouse model, the BRAF inhibitor PLX4720 suppressed growth of mutated human anaplastic thyroid cancer. A case report by Rosove et al was recently published in the New England Journal of Medicine. ${ }^{59}$

$\mathrm{PI} 3 \mathrm{~K} / \mathrm{mTOR}$ inhibitors are also under investigation at different levels of clinical studies. For example, BEZ235 reduces $\mathrm{PI} 3 \mathrm{~K}$ and $\mathrm{mTOR}$ kinase activity by competitive binding to the ATP-binding cleft of these enzymes. ${ }^{67,69,70,79}$

Table 2 reports the most significant trials on molecular target therapies used in ATC treatment. 


\section{Conclusion}

The outcome after treatment of ATC remains disappointing. However, knowledge about management of anaplastic tumors is increasing, and this information must be shared to improve outcomes. Indeed, this tumor was neglected by oncologists, and many doctors are still not informed about treatment options, in particular, drugs. The weakness of these studies on novel targeted agents is low accrual in clinical trials, also due to the rarity of the disease and its rapid evolution.

A multimodality approach should represent the standard treatment of choice in ATC, with surgery being the cornerstone of management of early stage patients. Notably, surgery remains the most important treatment modality when a complete resection may be obtained.

The role of preoperative or postoperative CRT remains controversial, although the use of both surgery and chemoradiation correlates with a better outcome.

A major concern of CRT is toxicity, which negatively impacts the completion of protocol. However, it improves both local and distant control, although it appears recommendable mostly for fit patients.

Because ATC management is very challenging, researchers look at emerging target therapies with a lot of interest. However, although there are promising results in preclinical development, only few studies on new molecules have been clinically confirmed. Clearly, a better understanding of the molecular pathogenesis driving the disease is required to define new therapeutic strategies. This knowledge might provide useful drugs to be used both alone or in combination with conventional methods. In short, the hope of a novel treatment strategy comes from unsatisfactory results from conventional therapies. An effort of every institution to allow clinical trials participation is required.

Confirmatory data from these new therapeutic strategies are needed.

\section{Acknowledgments}

The authors express thanks to Lawrence Preston for copyediting, and Lega Italiana Tumori, Sezione di Cuneo for fundraising.

\section{Disclosure}

The authors report no conflicts of interest in this work.

\section{References}

1. Nagaiah G, Hossain A, Mooney CJ, Parmentier J, Remick SC. Anaplastic thyroid cancer: a review of epidemiology, pathogenesis, and treatment. J Oncol. 2011;2011:542358.

2. Nikiforova MN, Nikiforov YE. Molecular diagnostics and predictors in thyroid cancer. Thyroid. 2009;19(12):1351-1361.
3. Smallridge RC, Marlow LA, Copland JA. Anaplastic thyroid cancer: molecular pathogenesis and emerging therapies. Endocr Relat Cancer. 2009;16(1):17-44.

4. Bible KC, Smallridge RC, Morris JC, et al. Development of a multidisciplinary, multicampus subspecialty practice in endocrine cancers. J Oncol Pract. 2012;8(Suppl 3):e1s-e5s.

5. Xing M. Genetic alterations in the phosphatidylinositol-3 kinase/Akt pathway in thyroid cancer. Thyroid. 2010;20(7):697-706.

6. García-Rostán G, Costa AM, Pereira-Castro I, et al. Mutation of the PIK3CA gene in anaplastic thyroid cancer. Cancer Res. 2005;65(22): 10199-10207.

7. Santarpia L, El-Naggar AK, Cote GJ, Myers JN, Sherman SI. Phosphatidylinositol 3-kinase/akt and ras/raf-mitogen-activated protein kinase pathway mutations in anaplastic thyroid cancer. J Clin Endocrinol Metab. 2008;93(1):278-284.

8. Liu D, Xing M. Potent inhibition of thyroid cancer cells by the MEK inhibitor PD0325901 and its potentiation by suppression of the PI3K and NF-kappaB pathways. Thyroid. 2008;18(8):853-864.

9. Ulisse S, Delcros JG, Baldini E, Toller M, et al. Expression of Aurora genes kinases in human thyroid carcinoma cell lines and tissues. Int $J$ Cancer. 2006;119(2):275-282.

10. Kim JH, Leeper RD. Treatment of anaplastic giant and spindle cell carcinoma of the thyroid gland with combination adriamycin and radiation therapy. A new approach. Cancer. 1983;52(6):954-957.

11. De Besi P, Busnardo B, Toso S, et al. Combined chemotherapy with bleomycin, adriamycin, and platinum in advanced thyroid cancer. J Endocrinol Invest. 1991;14(6):475-480.

12. Voigt W, Bulankin A, Muller T, et al. Schedule-dependent antagonism of gemcitabine and cisplatin in human anaplastic thyroid cancer cell lines. Clin Cancer Res. 2000;6(5):2087-2093.

13. Pushkarev VM, Starenki DV, Saenko VA, et al. Molecular mechanisms of the effects of low concentrations of taxol in anaplastic thyroid cancer cells. Endocrinology. 2004;145(7):3143-3152.

14. Ain KB, Egorin MJ, DeSimone PA. Treatment of anaplastic thyroid carcinoma with paclitaxel: phase 2 trial using ninety-six-hour infusion. Collaborative Anaplastic Thyroid Cancer Health Intervention Trials (CATCHIT) Group. Thyroid. 2000;10(7):587-594.

15. Higashiyama $T$, Ito $Y$, Hirokawa $M$, et al. Induction chemotherapy with weekly paclitaxel administration for anaplastic thyroid carcinoma. Thyroid. 2010;20(1):7-14.

16. Catalano MG, Poli R, Pugliese M, Fortunati N, Boccuzzi G. Valproic acid enhances tubulin acetylation and apoptotic activity of paclitaxel on anaplastic thyroid cancer cell lines. Endocr Relat Cancer. 2007;14(3): 839-845.

17. Voigt W, Kegel T, Weiss M, Mueller T, Simon H, Schmoll HJ. Potential activity of paclitaxel, vinorelbine and gemcitabine in anaplastic thyroid carcinoma. J Cancer Res Clin Oncol. 2005;131(9): 585-590.

18. Shimaoka K, Schoenfeld DA, DeWys WD, Creech RH, DeConti R. A randomized trial of doxorubicin versus doxorubicin plus cisplatin in patients with advanced thyroid carcinoma. Cancer. 1985;56(9): 2155-2221.

19. Wang S, Lloyd RV, Hutzler MJ, Safran MS, Patwardhan NA, Khan A. The role of cell cycle regulatory protein, cyclin D1, in the progression of thyroid cancer. Mod Pathol. 2000;13(8):882-887.

20. Wang Y, Tsang R, Asa S, Dickson B, Arenovich T, Brierley J. Clinical outcome of anaplastic thyroid carcinoma treated with radiotherapy of once- and twice-daily fractionation regimens. Cancer. 2006;107(8): 1786-1792.

21. Haigh PI, Ituarte PH, Wu HS, et al. Completely resected anaplastic thyroid carcinoma combined with adjuvant chemotherapy and irradiation is associated with prolonged survival. Cancer. 2001;91(12): 2335-2342.

22. Brignardello E, Gallo M, Baldi I, et al. Anaplastic thyroid carcinoma: clinical outcome of 30 consecutive patients referred to a single institution in the past 5 years. Eur J Endocrinol. 2007;156(4): 425-430.

23. Voutilainen PE, Multanen M, Haapiainen RK, Leppaniemi AK, Sivula AH. Anaplastic thyroid carcinoma survival. World J Surg. 1999;23(9):975-978; discussion 978-979. 
24. Tan RK, Finley RK III, Driscoll D, Bakamjian V, Hicks WL Jr, Shedd DP. Anaplastic carcinoma of the thyroid: a 24-year experience. Head Neck. 1995;1(1):41-47; discussion 47-48.

25. Veness MJ, Porter GS, Morgan GJ. Anaplastic thyroid carcinoma: dismal outcome despite current treatment approach. ANZ J Surg. 2004;74(7):559-562.

26. Schlumberger M, Parmentier C, Delisle MJ, Couette JE, Droz JP, Sarrazin D. Combination therapy for anaplastic giant cell thyroid carcinoma. Cancer. 1991;67(3):564-566.

27. Mitchell G, Huddart R, Harmer C. Phase II evaluation of high dose accelerated radiotherapy for anaplastic thyroid carcinoma. Radiother Oncol. 1999;50(1):33-38.

28. Besic N, Auersperg M, Us-Krasovec M, Golouh R, Frkovic-Grazio S, Vodnik A. Effect of primary treatment on survival in anaplastic thyroid carcinoma. Eur J Surg Oncol. 2001;27(3):260-264.

29. De Crevoisier R, Baudin E, Bachelot A, et al. Combined treatment of anaplastic thyroid carcinoma with surgery, chemotherapy, and hyperfractionated accelerated external radiotherapy. Int J Radiat Oncol Biol Phys. 2004;60(4):1137-1143.

30. Kobayashi T, Asakawa H, Umeshita K, et al. Treatment of 37 patients with anaplastic carcinoma of the thyroid. Head Neck. 1996;18(1):36-41

31. Swaak-Kragten AT, de Wilt JH, Schmitz PI, Bontenbal M, Levendag PC. Multimodality treatment for anaplastic thyroid carcinoma - treatment outcome in 75 patients. Radiother Oncol. 2009;92(1):100-104.

32. Vrbic S, Pejcic I, Vrbic M, Filipovic S. Therapy of stage IV B anaplastic thyroid carcinoma: single institution experience. J BUON. 2009;14(1): 41-44.

33. Yau T, Lo CY, Epstein RJ, Lam AK, Wan KY, Lang BH. Treatment outcomes in anaplastic thyroid carcinoma: survival improvement in young patients with localized disease treated by combination of surgery and radiotherapy. Ann Surg Oncol. 2008;15(9):2500-2505.

34. Lim SM, Shin SJ, Chung WY, et al. Treatment outcome of patients with anaplastic thyroid cancer: a single center experience. Yonsei Med J. 2012;53(2):352-357.

35. Lee JJ, Foukakis T, Hashemi J, et al. Molecular cytogenetic profiles of novel and established human anaplastic thyroid carcinoma models. Thyroid. 2007;17(4):289-301.

36. McIver B, Hay ID, Giuffrida DF, et al. Anaplastic thyroid carcinoma: a 50-year experience at a single institution. Surgery. 2001;130(6): $1028-1034$

37. Akaishi J, Sugino K, Kitagawa W, et al. Prognostic factors and treatment outcomes of 100 cases of anaplastic thyroid carcinoma. Thyroid. 2011;21(11):1183-1189.

38. Heron DE, Karimpour S, Grigsby PW. Anaplastic thyroid carcinoma: comparison of conventional radiotherapy and hyperfractionation chemoradiotherapy in two groups. Am J Clin Oncol. 2002;25(5): $442-446$.

39. Nilsson O, Lindeberg J, Zedenius J, et al. Anaplastic giant cell carcinoma of the thyroid gland: treatment and survival over a 25 -year period. World J Surg. 1998;22(7):725-730.

40. Tennvall J, Lundell G, Wahlberg P, et al. Anaplastic thyroid carcinoma: three protocols combining doxorubicin, hyperfractionated radiotherapy and surgery. Br J Cancer. 2002;86(12):1848-1853.

41. Junor EJ, Paul J, Reed NS. Anaplastic thyroid carcinoma: 91 patients treated by surgery and radiotherapy. Eur J Surg Oncol. 1992;18(2): 83-88.

42. Levendag PC, De Porre PM, van Putten WL. Anaplastic carcinoma of the thyroid gland treated by radiation therapy. Intl J Radiat Oncol Biol Phys. 1993;26:125-128.

43. Derbel O, Limem S, Ségura-Ferlay C, et al. Results of combined treatment of anaplastic thyroid carcinoma (ATC). BMC Cancer. 2011;11:469.

44. Kim S, Schiff BA, Yigitbasi OG, et al. Targeted molecular therapy of anaplastic thyroid carcinoma with AEE788. Mol Cancer Ther. 2005;4(4):632-640.
45. Nobuhara Y, Onoda N, Yamashita Y, et al. Efficacy of epidermal growth factor receptor-targeted molecular therapy in anaplastic thyroid cancer cell lines. Br J Cancer. 2005;92(6):1110-1116.

46. Kurebayashi J, Okubo S, Yamamoto Y, et al. Additive antitumor effects of gefitinib and imatinib on anaplastic thyroid cancer cells. Cancer Chemother Pharmacol. 2006;58(4):460-470.

47. Hoffmann S, Burchert A, Wunderlich A, et al. Differential effects of cetuximab and AEE 788 on epidermal growth factor receptor (EGF-R) and vascular endothelial growth factor receptor (VEGF-R) in thyroid cancer cell lines. Endocrine. 2007;31:105-113.

48. Podtcheko A, Ohtsuru A, Tsuda S, et al. The selective tyrosine kinase inhibitor, STI571, inhibits growth of anaplastic thyroid cancer cells. J Clin Endocrinol Metab. 2003;88:1889-1896.

49. Blagosklonny MV, Giannakakou P, Wojtowicz M, et al. Effects of p53-expressing adenovirus on the chemosensitivity and differentiation of anaplastic thyroid cancer cells. J Clin Endocrinol Metab. 1998;83: 2516-2522.

50. Bonofiglio D, Qi H, Gabriele S, et al. Peroxisome proliferator activated receptor $\gamma$ inhibits follicular and anaplastic thyroid carcinoma cells growth by upregulating p21Cip1/WAF1 gene in a Sp1-dependent manner. Endocr Relat Cancer 2008;15(2):545-557.

51. Fury MG, Solit DB, Su YB, et al. A phase I trial of intermittent highdose gefitinib and fixed-dose docetaxel in patients with advanced solid tumors. Cancer Chemother Pharmacol. 2007;59:467-475.

52. Cohen EEW, Rosen LS, Vokes EE, et al. Axitinib is an active treatment for all histologic subtypes of advanced thyroid cancer: results from a phase II study. J Clin Oncol. 2008;26:4708-4713.

53. Gupta-Abramson V, Troxel AB, Nellore A, et al. Phase II trial of sorafenib in advanced thyroid cancer. J Clin Oncol. 2008;26(29): 4714-4719.

54. Cho K, Wang X, Nie S, Chen ZG, Shin DM. Therapeutic nanoparticles for drug delivery in cancer. Clin Cancer Res. 2008;14:1310-1316.

55. Atadja P. Development of the pan-DAC inhibitor panobinostat (LBH589): successes and challenges. Cancer Lett. 2009;280(2):233-241.

56. Gule MK, Chen Y, Sano D, et al. Targeted therapy of VEGFR2 and EGFR significantly inhibits growth of anaplastic thyroid cancer in an orthotopic murine model. Clin Cancer Res. 2011;17(8):2281-2291.

57. Wunderlich A, Roth S, Ramaswamy A, et al. Combined inhibition of cellular pathways as a future therapeutic option in fatal anaplastic thyroid cancer. Endocrine. 2012;42(3):637-646.

58. Spallanzani A, Bertolini F, Depenni R, et al. Tyrosine kinase inhibitors (TKIs) in advanced thyroid cancer: a single institution report. Supplementi di Tumori. 2012;13(3):S99.

59. Rosove MH, Peddi PF, Glaspy JA. BRAF V600E inhibition in anaplastic thyroid cancer. $N$ Engl J Med. 2013;368(7):684-685.

60. Nehs MA, Nucera C, Nagarkatti SS, et al. Late intervention with anti-BRAF(V600E) therapy induces tumor regression in an orthotopic mouse model of human anaplastic thyroid cancer. Endocrinology. 2012;153:985-994.

61. Brown RF, Ducic Y. Aggressive surgical resection of anaplastic thyroid carcinoma may provide long-term survival in selected patients. Otolaryngol Head Neck Surg. 2013;148(4):564-571.

62. Sun XS, Sun SR, Guevara N, et al. Chemoradiation in anaplastic thyroid carcinomas. Crit Rev Oncol Hematol. 2012;86(3):290-301.

63. Deshpande HA, Roman S, Sosa JA. New targeted therapies and other advances in the management of anaplastic thyroid cancer. Curr Opin Oncol. 2013;25(1):44-49.

64. Pacini F, Castagna MG, Brilli L, Pentheroudakis G; ESMO Guidelines Working Group. Thyroid Cancer: ESMO Clinical Practice Guidelines for diagnosis, treatment and follow-up. Ann Oncol. 2012;23 Suppl 7: vii110-vii119.

65. Xing M. BRAF mutation in thyroid cancer. Endocr Relat Cancer. 2005;12(2):245-262.

66. Hou P, Liu D, Shan Y, et al. Genetic alterations and their relationship in the phosphatidylinositol 3-kinase/Akt pathway in thyroid cancer. Clin Cancer Res. 2007;13(4):1161-1170. 
67. Liu Z, Hou P, Ji M, Guan H, et al. Highly prevalent genetic alterations in receptor tyrosine kinases and phosphatidylinositol 3-kinase/ akt and mitogen-activated protein kinase pathways in anaplastic and follicular thyroid cancers. J Clin Endocrinol Metab. 2008;93(8): 3106-3116.

68. Caronia LM, Phay JE, Shah MH. Role of BRAF in thyroid oncogenesis. Clin Cancer Res. 2011;17(24):7511-7517.

69. Ricarte-Filho JC, Ryder M, Chitale DA, et al. Mutational profile of advanced primary and metastatic radioactive iodine-refractory thyroid cancers reveals distinct pathogenetic roles for BRAF, PIK3CA, and AKT1. Cancer Res. 2009;69(11):4885-4893.

70. Nehs MA, Nagarkatti S, Nucera C, Hodin RA, Parangi S. Thyroidectomy with neoadjuvant PLX4720 extends survival and decreases tumor burden in an orthotopic mouse model of anaplastic thyroid cancer. Surgery. 2010;148(6):1154-1162; discussion 1162.

71. Savvides P, Nagaiah G, Lavertu PN, et al. Phase II Trial of Sorafenib in patients with advanced anaplastic carcinoma of the thyroid. Thyroid. 2013;23(5):600-604.

72. Bayer. Nexavar ${ }^{\circledR}$ versus placebo in locally advanced $/$ metastatic RAI-refractory differentiated thyroid cancer. Available from: http:// www.clinicaltrials.gov/ct2/show/NCT00984282. NLM identifier: NCT00984282. Available form: www.clinicaltrials.gov/ct2/show/ NCT00984282. Accessed July 20, 2013.

73. Perri F, Lorenzo GD, Scarpati GD, Buonerba C. Anaplastic thyroid carcinoma: a comprehensive review of current and future therapeutic options. World J Clin Oncol. 2011;2(3):150-157.

74. Smallridge RC, Ain KB, Asa SL, et al; American Thyroid Association Anaplastic Thyroid Cancer Guidelines Taskforce. Thyroid. 2012 Nov;22(11):1104-39.

75. Cooney MM, van Heeckeren W, Bhakta S, Ortiz J, Remick SC. Drug insight: vascular disrupting agents and angiogenesis - novel approaches for drug delivery. Nat Clin Pract Oncol. 2006;3(12): 682-692.

76. Ha HT, Lee JS, Urba S, et al. A phase II study of imatinib in patients with advanced anaplastic thyroid cancer. Thyroid. 2010;20(9):975-980.
77. Jin N, Jiang T, Rosen DM, Nelkin BD, Ball DW. Dual inhibition of mitogen-activated protein kinase kinase and mammalian target of rapamycin in differentiated and anaplastic thyroid cancer. J Clin Endocrinol Metab. 2009;94(10):4107-4112.

78. Catalano MG, Fortunati N, Pugliese M, et al. Histone deacetylase inhibition modulates E-cadherin expression and suppresses migration and invasion of anaplastic thyroid cancer cells. J Clin Endocrinol Metab. 2012;97(7):E1150-E1159.

79. Papewalis C, Wuttke M, Schinner S, et al. Role of the novel mTOR inhibitor RAD001 (everolimus) in anaplastic thyroid cancer. Horm Metab Res. 2009;41(10):752-756.

80. O’Neill JP, Shaha AR. Anaplastic thyroid cancer. Oral Oncol. 2013; 49(7):702-706.

81. Ito K, Hanamura T, Murayama K, et al. Multimodality therapeutic outcomes in anaplastic thyroid carcinoma: improved survival in subgroups of patients with localized primary tumors. Head Neck. 2012;34(2): $230-237$.

82. Granata R, Locati L, Licitra L. Therapeutic strategies in the management of patients with metastatic anaplastic thyroid cancer: review of the current literature. Curr Opin Oncol. 2013;25(3):224-228.

83. Sosa JA, Elisei R, Jarzab B, et al. A randomized phase II/III trial of a tumor vascular disrupting agent fosbretabulin tromethamine (CA4P) with carboplatin (C) and paclitaxel (P) in anaplastic thyroid cancer (ATC): final survival analysis for the FACT trial. J Clin Oncol. 2011;29(Suppl):Abstr 5502. Available from: http://meetinglibrary.asco. org/content/78227-102. Accessed July 20, 2013.

84. Pierie JP, Muzikansky A, Gaz RD, Faquin WC, Ott MJ. The effect of surgery and radiotherapy on outcome of anaplastic thyroid carcinoma. Ann Surg Oncol. 2002 Jan-Feb;9(1):57-64.

85. Kim S, Prichard CN, Younes $\mathrm{MN}$, et al. Cetuximab and Irinotecan interact synergistically to inhibit the growth of orthotopic anaplastic thyroid carcinoma xenografts in nude mice. Clin Cancer Res. 2006 Jan $15 ; 12(2): 600-7$
OncoTargets and Therapy

\section{Publish your work in this journal}

OncoTargets and Therapy is an international, peer-reviewed, open access journal focusing on the pathological basis of all cancers, potential targets for therapy and treatment protocols employed to improve the management of cancer patients. The journal also focuses on the impact of management programs and new therapeutic agents and protocols on

\section{Dovepress}

patient perspectives such as quality of life, adherence and satisfaction The manuscript management system is completely online and includes a very quick and fair peer-review system, which is all easy to use. Visit http://www.dovepress.com/testimonials.php to read real quotes from published authors. 